\title{
DEVELOPING ENTREPRENEURIAL INTENTIONS THROUGH GAMIFICATION USING ONLINE BUSINESS CHALLENGES
}

\author{
J. RUIZALBA ${ }^{1}$, A. Soares ${ }^{1}$, A. Banoun ${ }^{2}$, M. Rodriguez Molina ${ }^{3}$ \\ ${ }^{1}$ University of West London (UNITED KINGDOM) \\ 2 EDC Paris (FRANCE) \\ 3 University of Granada (SPAIN) \\ jruizdealba@gmail.com, belafsoares@gmail.com, arnaud.banoun@gmail.com, \\ miromol.1971@gmail.com
}

\begin{abstract}
Purpose:
This paper describes the results of a research project aimed at investigating the moderating role of gamification on the development of entrepreneurial intentions through the use of online business challenges. Following the theory of planned behaviour (TPB) (Ajzen, 1991), a research framework is suggested and empirically tested which measures entrepreneurial intentions before and after the participation in an online competition. TPB attempts to predict individual's intentions to engage in a behaviour, arguing that behaviours depend on both motivation (intention) and ability (behavioral control) (Ajzen, 1991). In this study, entrepreneurial intentions are used as a predictor of entrepreneurial behaviour and are measured using the Entrepreneurial Intentions Questionnaire (based on Liñán and Chen, 2009; Liñán et al., 2011; Guerrero and Urbano, 2014; Ruizalba et al., 2015) before and after a gamified environment. Gamification refers to the use of game elements in non-gamified environments, (Deterding et al., 2011) such as in Higher Education (HE) contexts. The suggested research framework hypothesises that gamification has a positive impact on HE students' entrepreneurial intentions.
\end{abstract}

Design/methodology/approach:

In order to investigate the suggested hypotheses, a quantitative research strategy was implemented using questionnaires distributed online to participants. Data was collected with the help of Studyka along with Paris Business School (PSB). Studyka facilitates gamified environments providing online challenges to students all over the world. These challenges are real problems put forward by companies and monetary prizes are attributed to winners. Two questionnaires were implemented: one implemented before the challenge and another one at the end of the gamified activity. A total of 980 students participated, and 281 responded to the two questionnaires, enabling before and after comparisons.

Findings:

Data analysis is currently undergoing and a difference is expected between the two samples collected (that is, before and after participation in the online challenge).

Originality/value:

This research contributes to the literature by investigating the role of gamified environments on entrepreneurial intentions of HE students.

\section{References:}

Ajzen, I. (1991), The Theory of Planned Behaviour, Organizational behaviour and human decision processes, 50:179-211.

Deterding, S., Dixon, D., Khaled, R. and Nacke, L. (2011). From game design elements to gamefulness: Defining Gamification. Proceedings of MindTrek.

Linan, F., and Chen, Y.W. (2009), Development and cross-cultural application of a specific instrument to measure entrepreneurial intentions, Entrepreneurship Theory and Practice, 33(3):593-617.

Linan, F., Urbano, D. and Guerrero, M. (2011), Regional variations in entrepreneurial cognitions: Start-up intentions of university students in Spain, Entrepreneurship \& Regional Development, 23 (3-4):187-215.

Guerrero, M.; Urbano, D. (2014), Academics' start-up intentions and knowledge filters: an individual perspective of the knowledge spill over theory of entrepreneurship, Small Business Economics, 43(1):57-74.

Ruizalba, J., Vallespin, M., Martin-Sanchez, V., Rodriguez-Molina, M. (2015), The moderating role of gender on entrepreneurial intentions: A TPB perspective, Intangible Capital, 11(1):92-117.

Keywords: Gamification; Entrepreneurial Intentions; Higher Education 